\title{
Iglesias, identidad y plurirreligiosidad: una mirada al protestantismo histórico*
}

\author{
Loida Sardiñas Iglesias ${ }^{* *}$
}

Recibido: 3 de marzo de 2016. • Aprobado: 5 de abril de 2016.

\section{Resumen}

Los siguientes apuntes buscan dar un impulso temático a la perspectiva propia identitaria de los protestantismos históricos y al posicionamiento de esta tradición frente a diálogo interreligioso, como apenas posibilidad de encontrarnos con nosotros mismos, con nuestras protestas, nuestros vuelos y luchas. Ello nos guiará a la pregunta obligada por la situación de los protestantismos contemporáneos y por la continuidad/discontinuidad entre el proyecto y espíritu protestante originario y la compleja realidad de los protestantismos "realmente existentes". En un primer momento se propone una aproximación histórico-tipológica a los protestantismos latinoamericanos, a fin de definir un marco referencial común, y se ofrece una comprensión de la identidad protestante a partir del llamado "principio protestante"; en un segundo momento se expone la perspectiva evangélica histórica sobre el diálogo y las relaciones del protestantismo histórico con creyentes de otras religiones.

Palabras clave: protestantismo, principio protestante, diálogo, plurirreligiosidad, identidad, iglesias.

* Artículo vinculado al proyecto de investigación permanente de la Facultad de Teología de la Universidad Santo Tomás. Y socializado en el Congreso Trascendencia, espiritualidades y formas de ser, Universidad Santo Tomás de Bucaramanga, 28 de Agosto de $2015 .$.

** Teóloga y docente de la Facultad de Teología de la Universidad Santo Tomás y de la Pontificia Universidad Javeriana en Bogotá; es Doctora en Medicina por la Universidad de La Habana, Cuba; Magister en Ciencias Teológicas por la Universidad Bíblica Latinoamericana, en San José de Costa Rica; y Doctora en Teología por la Universidad de Hamburgo, Alemania. Correo electrónico: loidasardinas@usantotomas.edu.co 


\title{
Churches, identity and pluri-religiousness: a look at historical protestantism
}

\begin{abstract}
The following notes seek to give a thematic stimulus to the identity own perspective of historical Protestantism and the positioning of this tradition before an interfaith dialogue, as just a chance to meet with ourselves, with our protests, our flights and struggles. This will lead us to the obvious question about the situation of contemporary Protestantism and the continuity / discontinuity between the original Protestant project and spirit and the complex reality of the "really existing" Protestantisms. At first a historical-typological approach to Latin American Protestantism is proposed, in order to define a common reference framework, and an understanding of the Protestant identity from the so-called "Protestant principle" is offered; in a second stage a historic evangelical perspective on dialogue and relations of historic Protestantism with believers of other religions is presented.

Keywords: Protestantism, Protestant principle, dialogue, pluri-religiousness, identity, churches
\end{abstract}

\section{Eglises, identité et pluri-religiosité: un regard au protestantisme historiques)}

\section{Résumé}

Les notes suivantes cherchent à donner un élan thématique à la propre perspective identitaire des protestantismes historiques et au positionnement de cette tradition face à un dialogue interreligieux, comme à peine une possibilité de nous retrouver avec nous même, avec nos protestations, nos vols et nos luttes. Cela nous guidera à la question incontournable vu la situation des protestantismes contemporains et de la continuité/discontinuité entre le projet et l'esprit protestant originaire et la réalité complexe des protestantismes «existants réellement». Dans un premier lieu, on propose une approche historique-typologique aux protestantismes latino-américains, afin de définir un cadre référentiel commun, et on offre une compréhension de l'identité protestante à partir du «principe protestan»; en deuxième lieu on expose la perspective évangélique historique sur le dialogue et les relations du protestantisme historique avec des croyants d'autres religions. 
Mots-clés: Protestantisme, principe protestant, dialogue, pluri-religiosité, identité, églises.

Si el protestantismo aún es joven...

Si aún tiene el poder de seducir...

Si es tan fuerte como para poseer cuerpos y hacerlos bailar, volar y luchar. Todo depende de su poder para hacer que otras religiones y tradiciones sueñen. Tal vez no se conviertan al protestantismo, pero es seguro que se volverán más ligeras.

Rubem Alves ${ }^{1}$

El teólogo-poeta presbiteriano Rubem Alves apela a un núcleo común protestante e invita a recuperar en la tradición quincentenaria los sueños y la ligereza. El que apenas llevemos medio mileno de presencia del protestantismo histórico nos hace soñar con iglesias protestantes todavía jóvenes, que mantengan aún viva su fuerza de convocatoria, de protesta y de contestación y que sean capaces de "seducir, poseer cuerpos y hacerlos bailar, volar y luchar". Y tener como trasfondo su llamado, y en el contexto de esta celebración de la Reforma protestante, los siguientes apuntes buscan dar un impulso temático a la perspectiva propia identitaria de los protestantismos históricos y al posicionamiento de esta tradición frente al diálogo interreligioso, como apenas posibilidad de encontrarnos con nosotros mismos, con nuestras protestas, nuestros vuelos y luchas. Ello nos guiará a la pregunta obligada por la situación de los protestantismos contemporáneos y por la continuidad/discontinuidad entre el proyecto y espíritu protestante originario y la compleja realidad de los protestantismos "realmente existentes". En un primer momento se propone una aproximación histórico-tipológica a los protestantismos latinoamericanos, a fin de definir un marco referencial común, y se ofrece una comprensión de la identidad protestante a partir del llamado "principio protestante"; en un segundo momento se expone la perspectiva evangélica histórica sobre el diálogo y las relaciones del protestantismo histórico con creyentes de otras religiones.

1 R. Alves, "An invitation to dream", citado por L. Cervantes-Ortiz, "Protestantismo, protestantismos e identidad en América Latina y México", Ponencia XVI Congreso Nacional Estado, Iglesias y Grupos laicos, Universidad Autónoma de Puebla, 2002. 


\section{Tipología de los protestantismos en América Latina. El principio protestante.}

El fenómeno protestante hace referencia a un movimiento y unas iglesias surgidas a partir del siglo XVI como fruto de la Reforma iniciada por el monje agustino alemán Martín Lutero (1483-1546), que tienen un marco histórico-cultural y un tronco doctrinal común, así como desarrollos teológicos particulares, más o menos cercanos. ${ }^{2}$ Todas las iglesias protestantes surgen en Europa (centro-mundo del siglo decimosexto), y van a encontrar una continuidad histórica en otros continentes, constituyéndose como comunidades con carácter nacional. Ellas incluyen la tradición luterana (originaria de Alemania y expandida a Escandinavia), anglicana y metodista (Inglaterra y el ámbito de sus ex-colonias), calvinista (iglesias reformadas y presbiterianas inicialmente en Suiza, Escocia, Holanda), iglesias congregacionales y anabaptistas (menonitas, iglesia de los hermanos, bautistas, cuáqueros y pentecostales), llamadas estas últimas, de la "segunda reforma".

Este cristianismo protestante, también denominado grosso modo "evangéli$\mathrm{CO}^{\prime \prime}$, llega a América Latina directamente a través de los clérigos y fieles de las iglesias que emigraron de Europa durante la colonia, o a través de las iglesias nacidas en los Estados Unidos. Estudios varios sobre el protestantismo latinoamericano ${ }^{3}$ clasifican éste en cuatro grandes grupos, corrientes $u$ "olas" de migración protestante norteamericana o de iglesias autóctonas latinoamericanas: (a) el protestantismo histórico o liberal, (b) el protestantismo evangelical, (c) el

2 Diferenciado de la Iglesia católica romana y de la tradición ortodoxa, constituida a partir del primer gran cisma de la iglesia cristiana provocado de modo "oficial" entre oriente y occidente en el siglo XI (1054), el protestantismo comparte un núcleo doctrinal común, esto es, (1) la justificación por la fe, poniendo la primacía soteriológica en la justificación de pecados y la salvación sólo por la vía de la fe, al margen de la realización de obras justificadoras; y (2) el sacerdocio universal de los creyentes, como responsabilidad personal de cada cristiano/a por sus actos delante de Dios, frente la centralidad mediadora del clero; (3) la afirmación de sólo dos sacramentos instituidos evangélicamente, el Bautismo y la Eucaristía; entre otros aspectos.

3 Entre ellos Bastian, J. P. (1990), Historia del protestantismo en América Latina. (México: CUPSA); y (1983), Protestantismo y sociedad en México (México: CUPSA); el mismo autor como coordinador de la obra (2004) La modernidad religiosa: Europa latina y América Latina en perspectiva comparada, (México: FCE); Berg, M. y Pretiz, P. (1994) Mensajeros de esperanza: los evangélicos (Miami: UNILIT); Bonino, J. M. (1995) Rostros del protestantismo latinoamericano (Buenos Aires: Nueva Creación); Schäfer, H. (1992) Protestantismo y crisis social en América Central (San José: DEI); Moreno, P. (dir.), La acción social de las iglesias evangélicas en Colombia (Bogotá: CEDECOL). 
pentecostalismo y (d) el neo-pentecostalismo. Esta tipología nos permitiría describir tanto la relación de los diversos rostros del protestantismo latinoamericano con su historia y tradición originaria y con la sociedad latinoamericana receptora o de acogida, como exponer sus expresiones y concepciones doctrinales, espirituales, morales, misioneras y socio-pastorales.

\subsection{El protestantismo histórico o liberal.}

La primera migración u oleada protestante a América Latina ocurre a finales del siglo XIX con el arribo del movimiento misionero organizado por las iglesias históricas europeas y norteamericanas, los promotores de la Biblia y las sociedades bíblicas. En este grupo destacan las iglesias presbiteriana, episcopal (anglicana), metodista, bautista menonita, luterana, discípulos de Cristo y cuáqueros.

Este protestantismo, también denominado "liberal", tiene un enfoque misional dirigido a la educación, la salubridad y la preparación profesional, y una moral ascética de la "santidad de la vida común", basada en una dinámica antitética de vicios versus valores. Se trata de un protestantismo que logra articularse con las burguesías nacionales y con la clase media emergente, y centrarse en esfuerzos misioneros por "modernizar" y "civilizar" las sociedades tradicionales. Muchos de los misioneros de las iglesias en cuestión llegan a los países latinoamericanos con el apoyo y beneplácito de líderes liberales nacionales, que encontraron afinidades entre el protestantismo europeo y norteamericano, y los proyectos liberales dirigidos a la consecución del progreso y desarrollo de las naciones latinoamericanas. De este modo, a la par de una moral de la mesura y del cultivo espiritual, "la compostura y la seriedad del cuerpo, el puritanismo en la vida sexual, la laborariosidad enfrentada al ocio" (Amestoy, 2007: p. 21), el rechazo de los juegos de azar, del tabaco, las fiestas y el alcohol, se propician igualmente los valores liberales de la honradez, la moderación, el recato, la industriosidad, la búsqueda de superación, la deslegitimación del castigo físico de la niñez, de los obreros y delincuentes, la conciencia del deber y la responsabilidad individual, como disposiciones necesarias para la superación de la "barbarie y el atraso" y la afirmación de un proceso civilizatorio. En este sentido, en su expresión liberal social esta primera oleada protestante prioriza la educación y la salud, al crear 
clínicas, dispensarios médicos, colegios, asociaciones corales, literarias, librerías ambulantes (Sarayana, 2002: p. 165) ${ }^{4}$, espacios comunales de socialización,

donde recibir y continuar la instrucción e "ilustrarse" sanamente, donde cultivar camaraderías para toda la vida, donde elegir pareja y formar familia, lugares adecuados para crear mutuales, cooperativas y recibir el impulso inicial en la vida profesional, como así también para el ascenso social y el ejercicio del liderazgo. (Amestoy, 2007: p. 8).

Mucho se han cuestionado los móviles políticos, ideológicos y organizativos de la llegada a América Latina de un protestantismo "filtrado" por el proyecto liberal. De hecho, no se trata de que el liberalismo, como ideología de la burguesía latinoamericana, fundamentalmente cafetalera agroexportadora (Míguez \& Álvarez, 1983), fuese de cuño exclusivamente protestante. Más bien, se puede intuir que el protestantismo encontró núcleos comunes y compatibilidad con este proyecto liberal, siendo que en sus propias raíces se encuentran expresiones afirmativas de las libertades individuales, incluida la libertad religiosa, el discurso anti-clerical modernizador e individualista y la defensa del Estado de derecho.

[...] El protestantismo reclama y acepta el papel que las élites latinoamericanas le reconocen y asignan en la transición de la sociedad tradicional a la moderna. [...]. En alianza con liberales y particularmente con masones, luchará por la libertad religiosa y distintas secularizaciones (cementerios, escuelas, registro civil) necesarias para su propia supervivencia y expansión. En sus servicios educacionales, algunas de las iglesias (que algunas vez he llamado "misiones civilizadoras") intentan proveer un servicio de formación de élites ilustradas. Pero lo más importante es que ofrecen a las nacientes masas desarraigadas - sea por las migraciones a las primeras manifestaciones industriales o a los inmigrantes que en esta época ingresan en números crecientes a algunos países latinoamericanos - que comienzan a cortar el cordón umbilical con una estructura social y cultural que pretendía ser eterna, un nuevo estilo de vida, una religión para vivir en el nuevo mundo que se inicia. (Miguez, 1985: pp. 246-247)

4 Estas últimas buscaban difundir la Biblia en las versiones castellanas católicas más reconocidas, dado que la Palabra de Dios era utilizada para la alfabetización en las escuelas. (Saranyana, 2002: p. 165). 
A todas luces, se daban en América Latina las condiciones sociopolíticas idóneas para el despliegue del protestantismo liberal con enfoque en el evangelio social, como lo señala el teólogo católico José Ignacio Sarayana,

Al terminar las luchas por la emancipación política en la mayoría de las regiones coloniales latinoamericanas (1824), las estructuras de la Iglesia católica romana se hallaban extremadamente debilitadas. Para las nuevas élites liberales, el catolicismo significaba la encarnación de la cultura represiva ibérica [...]. La cultura francesa y anglosajona se presentaba como modelo alternativo, considerándose la componente protestante de esta última como fermento del progreso [...]. Los liberales allanaron el camino para la misión protestante [...]. (Sarayana, 2002: p. 163)

En América Latina este protestantismo liberal alcanza su auge y máxima expresión a mediados del siglo XX (alrededor de 1940), para luego disminuir su capacidad de crecimiento y de alguna manera estancarse. La diferencia del auge protestante entre los países, acorde a las situaciones políticas particulares, resulta sustantiva: así por ejemplo, mientras en México ya existían en 1892 unas 566 iglesias protestantes y en 1908 se establecen 700 congregaciones, en los países andinos como Colombia, Ecuador y Perú, la penetración y difusión del protestantismo resulta lenta, débil y difícil, al existir restricciones para la libertad religiosa y de culto, amén de presiones sociales importantes sobre los nuevos conversos, con acciones de persecución e incluso linchamientos en algunos casos. ${ }^{5}$

En la actualidad, el protestantismo histórico permanece en alguna medida estancado, en términos de crecimiento eclesial, pero mantiene su centralidad en el evangelio social y el carácter liberal de su teología, una ética cristiana comprometida con la justicia y la paz, y desde el punto de vista sociológico, su orientación a la clase media y su misión concentrada en la educación y la dignificación de la vida. (Schäfer, 1992: pp. 23-29)

5 En Colombia, este protestantismo se estableció inicialmente en las islas San Andrés y Providencia con el arribo de un grupo de puritanos ingleses alrededor de 1860, y posteriormente con el establecimiento allí de la Iglesia Bautista. Sin embargo, habría que señalar que una primera migración del protestantismo liberal más amplio no se inicia sino hasta después de 1940. 


\subsection{El protestantismo evangelical}

La segunda migración protestante tiene lugar en las primeras tres décadas del siglo XX y guarda relación con un esfuerzo misionero independiente, es decir, de misiones no orgánicamente vinculadas a las iglesias protestantes históricas, con fuertes matices fundamentalistas y conservadores. Son las llamadas "misiones de $\mathrm{fe}^{\mathrm{N}}$, con un perfil muy personalizado, centrado en la figura del "misionero-predicador". A diferencia del movimiento misionero liberal, el empuje económico de esta oleada provenía de ofrendas de creyentes y feligresía norteamericana. Estuvo dirigido no hacia el desarrollo social de las misiones in situ, sino a apoyar a los misioneros y sus familias, los cuales en su mayoría, según los investigadores Berg y Pretiz (Berg \& Pretiz, 1994), provenían mayoritariamente de sectores rurales, no tenían preparación teológica alguna, y expresaban un gran celo evangelístico y proselitista, un fervor y entusiasmo por la conversión y la salvación de las almas, muchas veces confundido con un anticatolicismo radical.

Este protestantismo, llamado en inglés evangelical (traducido por "pietista" o "evangelical", para diferenciarse del protestantismo liberal), resulta mucho más estricto en su moral pietista de ascesis intramundana: el "nacido de nuevo" debía afirmar los frutos espirituales de su conversión en el abstencionismo a los vicios y el moralismo sexual, además de existir una conciencia especial de "ser elegido", que ubica al misionero/a en una posición de superioridad moral respecto a las congregaciones y comunidades de fe. Manuales y panfletos de la época se concentran, no fundamentalmente en explicar el credo y los ritos de la fe protestante, los cuales pareciera ser irrelevantes, sino en indicar un repertorio detallado de conductas y hábitos que certifican el testimonio cristiano, en una especie de moral de prohibiciones. ${ }^{6}$

Este movimiento pone gran cuidado en no confundir o reemplazar la evangelización - las campañas de evangelismo dirigidas a la conversión personal constituyen su fuerte misionero - con la acción o responsabilidad social. En esta lógica, la tradición evangelical se define por su actitud intimista direccionada "hacia la práctica espiritual permeada por la lectura devocional de la Biblia, la oración y la moral del comportamiento como lo distintivo del cristiano" (Moreno, 2009: p. 16). En síntesis, a diferencia del protestantismo liberal, abierto a la modernidad y promotor del evangelio social, los evangélicos pietistas se oponen abiertamente al

6 Las indicaciones pueden abarcar desde cómo tratar y dirigirse adecuadamente al misionero-pastor, hasta como vestirse o de qué manera ingresar o conducirse en el templo. 
liberalismo (teológico y social), defienden la inerrancia de la Biblia, se refugian en la seguridad del literalismo y el fundamentalismo biblicista, tienen un discurso con tendencias apocalípticistas, definen su identidad por vía negativa a partir de un anti-catolicismo virulento, de carácter incluso agresivo, y moralmente, adoptan posiciones conservadoras y estrictas en temas de sexualidad, género y reproducción humana, etc. En los últimos años algunas corrientes de un "nuevo evangelicalismo" buscan acercarse a las tradiciones históricas y superar posturas separatistas y sectarias, aunque la mayoría de las iglesias evangelicales clásicas (carismáticos y neo-apostólicos) pasaron a formar parte del pentecostalismo.

\subsection{El pentecostalismo}

El tercer grupo de los protestantismos latinoamericanos se circunscribe al pentecostalismo, tanto al de origen norteamericano que arriba a América Latina en la posguerra, como a las nuevas denominaciones pentecostales autóctonas, nacionales, autosostenibles y autogobernadas. El movimiento y las iglesias pentecostales clásicas, fruto del pentecostalismo histórico de origen norteamericano de principios del siglo $\mathrm{XX}$, incluyen un gran número de denominaciones e iglesias independientes que enfatizan la acción del Espíritu Santo en la vida cristiana, dentro de las cuales se destacan en América Latina, las Asambleas de Dios, la Iglesia Internacional del Evangelio Cuadrangular, la Iglesia de Dios Pentecostal, la Iglesia de Santidad Pentecostal, la Pentecostal Unida, entre otras.

A diferencia de los dos anteriores grupos protestantes, centrados en la evangelización de las capas medias, los pentecostales se insertan privilegiadamente en los barrios y estratos más humildes de las sociedades latinoamericanas y en las zonas rurales, donde tienen gran influencia y logran impactar la vida cotidiana de muchas personas. Doctrinalmente, este movimiento se considera el auténtico depositario de la tradición y espíritu apostólico manifiesto en Pentecostés, de ahí su énfasis en la manifestación del Espíritu y en los dones espirituales, como el hablar en lenguas ${ }^{7}$, las sanidades, los milagros y exorcismos. Ha estado en sus orígenes marcado por la influencia de grupos y movimientos mileniaristas que consideran inminente la segunda venida de Cristo, lo que motiva la urgente labor evangelística y misionera. Así mismo, el movimiento clásico pentecostal sostiene

7 Habría que señalar que en los últimos años los pentecostalismos clásicos han restado importancia al don de lenguas como evidencia del "bautismo en el Espíritu", aun cuando se afirma su legitimidad como carisma. 
una comprensión de la vida cristiana en tres etapas progresivas: la conversión, la santificación y el bautismo en el Espíritu. Litúrgicamente, se destaca por el espontaneísmo y la emocionalidad en la práctica cultual, la expresión de la religiosidad centrada en la oralidad y lo testimonial, la participación de toda la comunidad en el culto cristiano, la crítica tanto al ritualismo católico, como al liberalismo y racionalismo protestante histórico centrado en la palabra (discurso y racionalidad), considerado además "extranjerizante" (Orellana, 2006: p. 26ss). Este pentecostalismo, en síntesis, se auto-propone como auténtica fe evangélica y una alternativa carismática al catolicismo y a los protestantismos históricos.

Un rasgo distintivo del pentecostalismo, que impacta a las otras expresiones cristianas, es la transformación que en él se opera de la cultura cultual, con un estilo de alabanza alegre y movido, una predicación más testimonial y carismática que teológica, una expresión pública de testimonios personales, la práctica del diezmo y la ministración de los dones espirituales diversos como marcas distintivas, amén de la latinoamericanización del culto cristiano, manifiesto en el uso de las guitarras e instrumentos de percusión, como reemplazo del órgano y el piano, presentes en la mayoría de las iglesias protestantes históricas.

El pentecostalismo ha sido considerado en los círculos académicos como una expresión eclesial poco desarrollada teológicamente, y con inclinación sectaria y expresamente anti-ecuménica. Esto se ha debido fundamentalmente al hecho de que:

La mayoría de las iglesias pentecostales han optado por no participar en ninguna organización ecuménica. Esto viene, en parte, de su perspectiva restauracionista sobre la historia de la iglesia, que considera que las iglesias existentes se han apartado de las intenciones de Dios al transigir y pecar. Otra razón es la manera en que muchas iglesias actuales han marginado y rechazado a los pentecostales cuando estos intentaban compartir sus testimonios sobre lo que Dios había hecho en sus vidas. Por consiguiente, el pensamiento sectario ha dominado gran parte del movimiento, que en muchos casos desarrolló una posición escatológica que temía el contacto ecuménico. (WCC; s. f.)

Sin embargo, la mayor parte de las iglesias pentecostales sostienen intercambios y se identifican con otras iglesias evangélicas. Recientemente se ha venido elaborando un cuerpo de teología pentecostal que ha reflexionado en los credos 
pentecostales particulares y en temas de carisma y burocratización de la fe, poder y autoridad en la iglesia, participación política, entre otros temas. ${ }^{8}$

\subsection{El neopentecostalismo}

Un cuarto grupo fruto de los protestantismos, aun cuando no se reconoce a sí mismo dentro de la tradición "protestante", ni sea reconocido parte integrante de la familia protestante, resulta el movimiento neo-pentecostal, componente fundamental de los nuevos movimientos religiosos ("NMR") de matriz cristiana evangélica. Se trata de un fenómeno que hace parte de lo que Jean-Pierre Bastian denomina la "recomposición" del rostro religioso contemporáneo:

Un primer rasgo de las recomposiciones que están teniendo lugar es el despliegue de una lógica de mercado que favorece la concurrencia religiosa, desestabiliza a la Iglesia católica y 'latiniza' especialmente los movimientos religiosos pentecostales. Esta pluralización no se basa, como en el contexto europeo, en una individualización de los actores religiosos, sino en la creación de poderosos actores colectivos en competencia. En la región latinoamericana, este proceso no se efectúa mediante un movimiento de repliegue de lo religioso hacia el espacio privado, sino en un movimiento de conquista del espacio público. Los diferentes actores religiosos, se movilizan en torno a partidos políticos confesionales. [...] Podrá hablarse, sin lugar a dudas, de una modernidad religiosa paradójica en el sentido de que el paradigma de la secularización es problemático. (Bastian, 2004: pp. 11-12)

Efectivamente, el movimiento y las iglesias neopentecostales, surgidas principalmente como escisiones en el seno del pentecostalismo, tienen una mayor orientación al espacio de lo público, especialmente de lo político-público y hacen uso intensivo de los medios de comunicación de masas, con una fuerte inversión

8 Según la World Christian Database (en: http://www.worldchristiandatabase.org/ wcd/), el número de pentecostales alrededor del mundo se encuentra alrededor de los 600 millones, sumando los pentecostales clásicos 78 millones, los carismáticos 192 millones y los neocarismáticos, 318 millones. Se estima, por parte del Hartford Institute for Religion Research (Instituto Hartford para la Investigación de la Religión) que los pentecostales constituyen el 45 por ciento de todos los cristianos (incluidos católicos, ortodoxos y protestantes) y el 70 por ciento de los 900 millones de evangélicos o protestantes que hay en el mundo. Se estima que para el 2025 el número de pentecostales en el mundo alcanzará los 1000 millones. 
en los medios electrónicos, especialmente de la televisión, lo que se muestra en las llamadas "iglesias electrónicas". Se dirigen privilegiadamente a los sectores de clase media, aunque también se encuentran altamente representados los sectores más populares y tienen ascendencia en las clases altas. Además de presentar una propuesta litúrgica más relajada, informal y emotiva, sus congregaciones actúan como organizaciones donde es posible, para estos sectores, ampliar las relaciones sociales. Sus templos o lugares de culto, que paulatinamente dejan de ser las otrora pequeñas y sencillas casas-culto para posicionarse como grandes construcciones llamativas que pueden alcanzar la categoría de mega-iglesias ${ }^{9}$, están dirigidas por líderes carismáticos con función de autoridad, capacidad para el mercadeo y el manejo social de multitudes, alrededor de los cuales se nuclean los diferentes ministerios establecidos. Políticamente, hacen énfasis en la participación partidista, con el objeto de ejercer influencia social y provocar transformaciones y cambios necesarios, cuyo fin mediato es la evangelización.

Presentan un énfasis en la sanación, con experiencias liberadoras, exorcistas y terapéuticas, algunas de ellas vinculadas a la llamada "guerra espiritual" y en muchos círculos se predica y difunde la llamada teología de la prosperidad o evangelio de la prosperidad (también conocida como teología del pacto o de la siembra), con cierto énfasis en la prosperidad y el éxito como manifestaciones externas visibles de la gracia y la bendición de Dios en la vida del creyente. Están liberados de los estereotipos clásicos de santidad de la moralidad pentecostal y del ascetismo intramundano, para integrarse muy bien a las costumbres modernas, y especialmente a las propias de las subculturas urbanas y juveniles; mantienen una centralidad en una propuesta musical especializada y la expresión corporal (teatro, mímica, danza); sostienen escasa o nula relación con los otros grupos cristianos, sin estar interesados en el ecumenismo y suelen ubicarse en las zonas urbanas centrales de las ciudades más importantes, desde donde se expanden a otras regiones o países.

Resulta evidente que las manifestaciones pentecostales y neopentecostales del protestantismo han crecido rápidamente en muchas regiones del mundo, lo que representa un desafío in crescendo para el protestantismo histórico y el catolicismo romano. Indiscutiblemente, el neopentecostalismo ha resultado atrayente para algunos sectores de los protestantismos históricos, evangelicales y pentecostales, e incluso dentro del catolicismo para creyentes nominales que no han

9 Se entiende por mega-iglesias aquellas congregaciones con asistencia promedio de 2.000 o más personas en sus celebraciones dominicales principales. 
tenido relación previa con el ámbito evangélico, en la medida en que ha propagado la doble pertenencia. En términos de los desafíos que entraña la presencia avasalladora del neopentecostalismo, éste puede concebirse como una nueva forma de religiosidad que en su aspecto externo espontáneo, emocional y de diseño mediático, responde a vacíos creados por el racionalismo protestante; y en su integración y "estar en el mundo" desafía el segregacionismo de los pentecostalismos tradicionales.

\section{5. ¿Una identidad protestante? El principio protestante}

Lo sobresaliente de esta aproximación tipológica a los protestantismos latinoamericanos, es sin duda la multiplicidad y diversidad de rostros, manifestaciones e identidades protestantes que muestra. No existe, en el decir de Jean-Pierre Bastian, un único protestantismo, ni nos es posible definirlo de manera unívoca. Protestantismo viene a ser sinónimo en nuestro continente, de religiosidad múltiple, compleja, heterogénea y amorfa. Sin embargo, aún a sabiendas de la amplitud del término protestantismos - en plural- y de las experiencias eclesiales diversas a las que remite, y so pena de caer en el sesgo de la generalización, vale la pena intentar identificar aquello que constituye la constante, el núcleo común y matricial donde convergen los protestantismos concretos, y que puede asumirse como el principio protestante.

Puede afirmarse que el principio protestante constituye el horizonte de sentido que está en el origen mismo de la Reforma protestante, y que ha permanecido al menos en lo substancial en las manifestaciones reales, culturales, históricas, concretas y contextuales del protestantismo histórico y en algunas de las actuales denominaciones protestantes. Este principio protestante nos permitiría una identificación criteriada de lo auténticamente protestante. No se trata, en manera alguna, de buscar homogeneizar las diferencias, que sin duda resultan imposibles de reconciliar, y que por demás constituyen una de las riquezas identitarias del protestantismo; tampoco de presentar modelos teológicos, litúrgicos o pastorales únicos o dominantes, sino más bien de reconocer los “depósitos doctrinales" y teológicos presentes, mas no siempre conscientemente referenciados e identificados, del legado histórico protestante.

Cuando el teólogo Paul Tillich - al aproximarse a Karl Barth y a la teología dialéctica- habla del principio protestante se refiere a una especie de racionalidad o "lógica" de la protesta, de la crítica, de la sospecha, del carácter protestatario frente a todo lo que institucionaliza la fe, lo que normativiza y coopta la libertad 
con la que Cristo nos hace libres. Se trata del principio que está presente y a la base de la propia Reforma protestante. Este principio protestante proviene de la protesta y la crítica, de la capacidad potencial y del acto mismo de rebeldía contra toda pretensión de institucionalización de la fe (en la tensión, religión vs. fe liberadora). Este principio-criterio puede, incluso, no estar ya presente en muchas de las iglesias protestantes actualmente existentes, y de hecho, Tillich no habla de "iglesias protestantes", sino del protestantismo en tanto movimiento más universal. Pero, a nosotros corresponde el intento de identificar en nuestras tradiciones y comunidades eclesiales actuales la pervivencia o no de estos principios nucleares básicos, de esta raíz primigenia común, de una "protestantidad" auténtica en las expresiones eclesiales encarnadas.

Entre estos principios protestantes, que se encuentran a la base del protestantismo histórico y que conviene comprender y reactualizar a la luz de las múltiples tradiciones protestantes, se encuentran las así llamadas "cinco solas", que a continuación se explicita de manera resumida.

1. Solo a Dios la gloria: Es el principio que afirma a Dios como el absoluto dueño de la historia, en la medida en que la historia terrena es la historia de Dios mismo, presente en, interesado por y actuante en la humanidad. Porque Dios se hace presente y ocupa toda la dimensión del mundo, todo cuanto hacemos y pensamos ha de estar dirigido a Dios. La pregunta permanente en el espíritu protestante ha de ser: ¿cuál es la voluntad de Dios para el creyente; qué quiere Dios que haga? Una pregunta que abarca la vida toda, la cotidianidad, los intereses y deseos, la familia, la profesión, la responsabilidad social, etc. Conocer la voluntad de Dios se convierte en el centro de la vida creyente. Esto implica, no sólo la relación propia del protestantismo de permanente oración e íntima búsqueda de Dios para discernir e identificar su voluntad para mi vida y mi presente, sino también una actitud positiva del protestante hacia la historia que puede sintetizarse en la convicción teleológica de que Dios dirigirá finalmente todas las cosas, pues Dios es el antes y el consumador de todo y en este sentido se inscribe la afirmación de Calvino: "la historia tiene un fin divino".

2. Sacerdocio universal de los creyentes: Asevera que todos los seres humanos son iguales ante Dios, que toda creatura es imago dei, y por tanto se puede y se debe establecer una relación personal y directa con Dios, 
sin mediadores humanos entre Dios y los hombres, solo Jesucristo, Dios encarnado. El presupuesto para tal afirmación es la concepción tomista de que el ser humano no es individuo, sino persona (substancia individual de naturaleza racional) y que como tal tiene una dignidad y una capacidad - potencialidad, por el simple hecho de ser persona, para relacionarse y comunicarse con Dios. Ahora bien, esta relación directa con Dios implica que el creyente-sacerdote, no puede descansar su responsabilidad ante las instancias heterónomas (la iglesia, el pastor o líder local, la Biblia, etc.); significa que el creyente autónomo asume una responsabilidad ante la comunidad que es la iglesia, ante la comunidad que es la humanidad, ante la comunidad que es el mundo-creación. El sacerdocio universal reafirma el carácter social y de responsabilidad del creyente ante el mundo.

3. Sola Scriptura, sola gratia, sola fide: Constituyen los principios rectores que permitieron a las iglesias de la Reforma derribar los muros existentes para sacar al cristianismo de las iglesias hacia el mundo y la sociedad.

a. La sola Scriptura o "solo por medio de la Escritura" resulta aquel principio formal, fuente y norma de la sola fide, que constituye el principio material. La sola Scriptura indica la centralidad de la Escritura, como única norma de fe y conducta cristiana, divinamente inspirada. Es un principio que actúa como una especie de "magisterio invisible" en el protestantismo, cuya señal externa más visible es el de poseer, portar y aprender el texto sagrado, de manera que en algunas corrientes protestantes el llevar la Biblia bajo el brazo para asistir al culto, la existencia de un ejemplar en cada hogar, la memorización de versículos, el concursar para comprobar el aprendizaje de los textos bíblicos, se constituyen "marcas" del protestante. Para el protestantismo se trata fundamentalmente de identificar aquellos fundamentos bíblicos y teológicos que se deprenden de las Escrituras y que nos permiten dar razones de la esperanza subyacente a la fe cristiana (cf. 1 Ped 3, 15). Obviamente, es un principio que no implica la deificación del texto sagrado, ni la suplantación de Dios por su Palabra. Si a partir del conocimiento escriturístico se arriba a una mejor exposición de la fe cristiana, el tema de fondo aquí no es la centralidad de la Palabra revelada como primera fuente teológica, sino la cuestión hermenéutica sobre quien es el sujeto intérprete de 
la Biblia, una función que en el protestantismo clásico va a descansar en el creyente - estudioso del texto -, y en la comunidad de fe.

b. La sola gratia indica que la salvación sólo acontece por la gracia y es don de Dios, en virtud de la fe que confía en Dios, no en virtud de las propias obras piadosas. La paradoja que subyace aquí es el saber que por nuestros propios méritos no podemos cumplir con las exigencias de la fe; y a la vez insistimos en obedecer a Dios; el creyente se reconoce pecador, pero sabe que con la ayuda de Dios, a través de su Espíritu, puede luchar contra el pecado y su manifestación en el mundo. La sola gratia implica un convencido optimismo: el saber que somos pecadores pero que vivimos bajo la gracia de Dios otorga libertad.

c. Justificación por la fe (sola fide): principio que indica que el pecador es justificado - hallado justo - solo por la fe; es decir, que la justificación o el ser declarado justo por Dios, se recibe por la fe. Resulta evidente, sin embargo, y contra toda interpretación simplista y superficial de la sola fide, que para la teología protestante clásica la fe salvadora se evidencia a través de la sus mediaciones - criterio de validación o verificación de la fe auténtica cristiana -, que son los frutos o buenas obras: el ser declarado justos implica el hacer/realizar obras de justicia. El justificado solo puede actuar justamente. No puede quedarse a nivel de decisiones íntimas de la fe pietista. Por otro lado, este nivel de fides indica una confianza plena en Dios, una espera y abandono en Dios. No se puede ser protestante si se carece de esperanza, pues la vida cristiana es vida en espera; una esperanza que anticipa, por la fe, la actuación misericordiosa de Dios en el acontecer de lo humano. En resumen, se trata de un principio (en el sentido fundamental y de argumentación de principium) que pone la fe a la base de las obras: la afirmación de que la fe produce justificación y buenas obras, diferente a aquella que sostiene que la fe y las buenas obras conllevan a la justificación.

Si como afirma Jürgen Habermas, la sociedad moderna descansa en tres pilares que son el Renacimiento, la Revolución francesa y la Reforma protestante, la pregunta obligada frente al principio protestante es si realmente resulta aquel núcleo duro y fundante de la Reforma que no es posible perder. En su actualización y vigencia en las comunidades concretas de un protestantismo histórico contemporáneo, tendremos que discernir si se ha llegado a una asunción meramente 
formal de tales principios o si en la práctica eclesial evangélica existe un conocimiento y aplicación real de sus contenidos. En otras palabras, conviene plantearnos si el principio protestante permanece en el movimiento de las iglesias hijas de la Reforma, apenas como aquel recuerdo, memoria de la tradición original, o si hay pervivencia en la teología y las prácticas concretas del sentido y las transformaciones propuestas por Martín Lutero y los otros reformadores. Corremos el riesgo, por supuesto, de desviar la cuestión a una búsqueda de cierto purismo doctrinal, por demás irrelevante. Sin embargo, se considera que más allá de los procesos de rutinización de los carismas, de la burocratización de movimientos espontaneístas en su origen, y de la institucionalización de la fe, resulta necesario apelar a la validez de estos criterios-marco, a una axiología y una matriz común que afirma que el protestantismo ha de ser esencialmente,

1. Reformador: lo que se evidencia en el primitivo entusiasmo reformador, en el sentido y la direccionalidad de la crítica, que no dan lugar a la contemporánea asunción acrítica de modelos evangelicales importados;

2. Participativo: a partir del principio del sacerdocio universal de los creyentes se privilegia la participación del laicado en el cáliz de la comunión durante la celerbación de la Santa Cena, en la ordenación de las mujeres, en los gobiernos eclesiales locales con fuerte participación laical, entre otros aspectos. Ello, sin dejar de ser conscientes de las estructuras autoritarias que también se establecen a su interior cuando pastores o lideres eclesiales se autoconsideran dueños absolutos de la verdad y exponen una hemenéutica antojadiza según los principios del marketing neo-liberal ${ }^{10}$;

3. Plural: por ser considerada en muchos países y continentes como minoría religiosa, las tradiciones evangélicas han sido colocadas en una sola categoría, borrándose su diversidad y especificidad. Tendríamos que insistir en la diferenciación y heterogeneidad que ha marcado al protestantismo desde sus orígenes, pero igualmente preguntarnos si en la actualidad aparece esta diferenciación como expresión de rostros diferenciados o apenas como máscaras (Miguez, 1985);

4. Iconoclasta: conviene redefinir qué se entiende por idolatría, cuando se afirma la radical no adoración de otros dioses, frente a la acrítica aceptación en muchas comunidades de dioses de mercado. Se impone, así

10 En este sentido, por ejemplo, en los neo-evangelicalismos prosperistas existe la figura del "apóstol" que detenta el "magisterio" o "depósito de la fe". 
mismo, una revisión de algunos temas tabú, como la relación con María virgen, hermana, compañera de camino, que en la tradición de los reformadores es alabada y cuya intercesión se solícita;

5. Centrado en las Escrituras: el reconocimiento de la Biblia como autoridad suprema, mas no única, y la aproximación no literalista, no biblicista meramente formal de citación de versos o colecciones textuales, ni deificada de las Escrituras;

6. De la gracia: un protestantismo de la gratuidad, del don, de la participación en el misterio de Dios, por la sola gratia de Dios, que renuncie principistamente a un restablecimiento de las indugencias y los valores económicos que reemplazan la gracia, donde la salvación deja de ser gratuita y depende de una "inversión" o mercantilización de la fe, remitiéndose a una teología sacrificial que impone pagar un precio por la salvación; una salvación que ya no es fruto del seguimiento de Jesús a través de ministerios, sino a través de una participación en los diezmos y ofrendas.

\section{Protestantismo y diálogo interreligioso.}

Una vez explicitado el marco referencial e histórico de la fe, la teología y la praxis de un protestantismo situado en el espíritu de la protestandidad, se considera conveniente abordar un tema contemporáneo que define al más auténtico espíritu ecuménico protestante: los posicionamientos de las denominaciones y comunidades protestantes frente al diálogo interreligioso. Las discusiones y aportes de las iglesias protestantes históricas sobre las tradiciones y confesiones no cristianas, y sobre el necesario diálogo teológico, histórico, testimonial, social, etc., entre el cristianismo y las diversas religiones, han estado marcadas por aciertos y desaciertos varios, que se intentarán abordar en los seis apartados que siguen, desde documentos y declaraciones que hacen parte del acervo teológico 
de las iglesias y denominaciones protestantes históricas y del Consejo Mundial de Iglesias ${ }^{11}$ y la Alianza Evangélica Mundial12.

\subsection{El punto de partida: la plurirreligiosidad}

El punto de partida del acercamiento y encuentro protestante con la dialogicidad interreligiosa, es el reconocimiento de habitar un mundo religiosamente plural, conformado por sociedades portadoras de un universo de vivencias y experiencias no solo amplias y diversas, sino también paradójicas y ambivalentes alrededor de la religión. Por un lado, continuamente los analistas sociales señalan el origen religioso de la mayoría de los problemas y conflictos que aquejan a la humanidad: el terrorismo, la violencia y la confrontación interétnica y racial entre los pueblos tiene su génesis y fundamento, en no pocas ocasiones, en el fanatismo religioso militante y en los sistemas extremistas de fe y creencias. Desde esta perspectiva, la religión contiene para algunos, el germen de las principales patologías sociales contemporáneas.

Por otro lado, y paralelamente, la mayoría de las comunidades religiosas y los creyentes ven en la religión la única salida viable a la violencia, la corrupción moral y la desesperanza, hasta se llega a afirmar que solo la mediación religiosa y concretamente, los valores religiosos y el testimonio creyente de los fieles, podrían conducir a la humanidad a la paz y la reconciliación. Esta afirmación está anclada "en el creciente reconocimiento de la interdependencia de la vida humana y de la necesidad de colaborar a través de barreras religiosas para afrontar la violencia y los acuciantes problemas del mundo". (Consejo Mundial de Iglesias, 2002: p. 2)

11 El Consejo Mundial de Iglesias (CMI, o WCC por sus siglas en inglés, World Council of Churches) es la organización dedicada al tema y praxis de la ecumene y unidad de los cristianos más representativa y amplia a nivel mundial. Agrupa a unas 349 iglesias, denominaciones y comunidades cristianas en más de 110 países, distribuidas en los cinco continentes, y representa a unos 560 millones de cristianos de las iglesias ortodoxas, anglicanas, luteranas, reformadas, metodistas, bautistas, iglesias pentecostales e independientes. Cf. Consejo Mundial de Iglesias, "Quiénes somos", en: https://www.oikoumene.org/es/about-us (consultada en agosto 2 de 2015).

12 La Alianza Evangélica Mundial (WEA por sus siglas en inglés, World Evangelical Alliance) es una red mundial de iglesias evangélicas y organizaciones eclesiales en 120 países, que "se esfuerzan por aportar identidad, voz y plataforma" a los cristianos evangélicos en su misión de "vivir y proclamar las Buenas Nuevas de Jesús en sus comunidades". WEA, "Introducción", en: http://www.worldea.org/whoweare/introduction-spanish (consultada en agosto 2 de 2015). 
Sin embargo, lamentablemente resulta innegable que la mayor parte de las tradiciones religiosas del mundo tienen su propia historia de privilegios, complicidad con la violencia y compromisos con el poder político. El cristianismo mismo ha sido exponente del mensaje de amor incondicional y de gratuidad para todos los seres humanos y pueblos (Hch 17, 22-28), pero su historia ha estado profundamente marcada por la violencia ejercida contra pueblos enteros en nombre del Dios cristiano. De la barbarie resultante de la complicidad con los intereses coloniales, por ejemplo, dan fe las invasiones al continente africano por parte de los Estados confesionales protestantes europeos. Esta situación de ambigüedad nos ayuda a evitar una actitud romántica hacia las religiones, a la vez que valorar en su justa medida la doble expresión social de las religiones. Ella ha sido fuerza desestabilizadora a la vez que potencial transformador; causante de temor a la vez que fuente y origen de esperanza.

Este contexto de plurirreligiosidad, con todo y su ambivalencia, anuncia a la vez un elemento central a tomar en cuenta: el despertar, reactivamiento o resurgir de la creencia religiosa es una cuestión propia del nuevo milenio. El pasado siglo XX del occidente cristiano, portador de corrientes secularistas modernas, acrecentador de la increencia, de la desacralización de la vida religiosa, de la desinstitucionalización de la fe y la descristianización de la cultura, desplazó a la religión hacia la periferia de la vida pública. El clima socio-cultural secularizado, propició que el protagonismo que antes tuviera la religión y el universo simbólico religioso en la vida pública, fuera asumido por otras instituciones sociales no religiosas. Para algunos, se trata de la llegada del ser humano autónomo a esa mayoría de edad predicada por I. Kant, por la vía de un necesario “desencantamiento del mundo" (Entzauberung der Welt) ${ }^{13}$.

El universo simbólico eclesiástico-cristiano apenas es capaz de dar sentido y de iluminar el camino a otros ámbitos de la historia. Las realidades históricas y naturales se emancipan de toda tutela religiosa. La filosofía deja de ser la "esclava de la teología". La ética se torna autónoma. El arte se rige por las reglas de la estética y no por normas morales. La cultura tiene un sello laico y no la marca religiosa de épocas pasadas. Ninguna realidad requiere ser legitimada por la religión para tener consistencia. (Tamayo, 2004: pp. 29-30)

13 Concepto utilizado por el sociólogo alemán Max Weber en su estudio sobre la sociología de la religión, Wissenschaft als Beruf, de 1917. 
Al margen de consideraciones sobre los efectos positivos y negativos del fenómeno de la secularización en las sociedades modernas, lo cierto es que las filosofías, las ideologías, la ética, el arte, la cultura y las teorías sociales no lograron dar respuesta a las demandas espirituales profundas del ser humano moderno autónomo, ni encauzar sus esfuerzos por superar las injusticias y la fragmentariedad social, a la manera como lo han hecho las religiones. En un mundo dominado por lógicas de violencia y desesperanza y frente a la manifestación de una "cultura de muerte y del suicidio colectivo" (Hinkelammert, 1995) ${ }^{14}$ moderno y tardo-moderno, las personas buscan cada vez con mayor amplitud, un lugar de vida y plenitud en la religión; buscan esperanza y sentido de existencia en la fe y la creencia.

Es en este sentido que se afirma que la religión ha resurgido en el tiempo presente como un importante agente público, social y político, al ejercer una gran influencia en los asuntos del mundo contemporáneo. El impacto de la religión en la vida cotidiana, en las dinámicas propias de las comunidades y en la esfera pública de la sociedad, incluso en países con clara distinción y separación entre religión y Estado, hace predecir el presente siglo XXI como la "era de la religión".

Tal resurgir de la religión, sin embargo, no resulta lineal, ni sigue los patrones de las religiosidades tradicionales. Es decir, se trata de un "retorno a lo religioso", más no una vuelta a las religiones tradicionales en su papel hegemónico social, ni en su institucionalidad clásica. Ello es posible argumentarlo a partir del ejemplo que aporta el propio cristianismo, cuyas expresiones institucionales tradicionales en muchas partes del mundo se encuentran en un cierto nivel de decadencia:

a. Las personas que buscan nuevas formas de compromiso religioso no siempre están vinculadas a las religiones oficiales, sino que hacen eco de la separación cada vez más acentuada entre fe personal, por un lado, y pertenencia institucional, por otro;

b. La globalización mediática, tecnológica y de movilidad, así como las migraciones de personas de otras religiones (hindúes, musulmanes, budistas, judíos, etc.) a los países occidentales están acrecentando la conciencia de superación de un hegemonismo y unilateralismo religioso cristiano en las sociedades de Occidente - fundamentalmente de los llamados países centrales, Europa y Norteamérica -, a la vez que ha

14 Así describe el economista alemán Franz Hinkelammert la mística del suicidio colectivo generalizada en la sociedad moderna y contemporánea globalizada, tendiente a la socavación de las fuentes naturales y sociales de la propia sobrevivencia humana, por tanto de la posibilidad de producción y reproducción de la vida. (Hinkelammert, 1985) 
suscitado la reciprocidad e intercambio social e informativo entre personas cristianas y de otras religiones;

c. Aumenta la conciencia crítica frente a las prácticas "cristianizadoras" o de un evangelismo misional de acercamiento a las otras religiones con fines proselitistas, llamándose la atención sobre la posibilidad de recurrir ilegítimamente al diálogo como un nuevo instrumento para la misión, lo que acentúa las controversias sobre el tipo de evangelización que se propone y sobre la libertad de expresión y las práctica religiosas plurales.

Se trata, a partir de estos ejemplos, de un nuevo contexto en el cual el cristianismo se reconfigura a consecuencia de los nuevos encuentros y relaciones con otras expresiones y manifestaciones de lo religioso y en el que no es considerado más como la única "religión-centro-mundo", con lo que ha perdido su hegemonismo histórico.

\subsection{Sociedades plurirreligiosas e identidad cristiana.}

Resulta evidente que el "retorno a lo religioso" que se ha dado de forma no lineal en nuestros días, ocurre en un marco de autonomía del sujeto religioso, de conciencia crítica de la institucionalidad simbólico-eclesial, y de movilidad, permeabilidad e intercambio entre las diversas manifestaciones religiosas. Ello posibilita que las sociedades occidentales cristianas y/o secularizadas, tradicionalmente homogéneas - de mayorías católicas en América Latina o predominantemente protestantes en los países nórdicos, por ejemplo-, desde un punto de vista religioso sean sustituidas por sociedades plurirreligiosas.

A partir de este nuevo contexto de sociedades plurales y plurirreligiosas, la teología cristiana se pregunta por el impacto de la interreligiosidad en la (re)conformación y (re)configuración de la identidad cristiana. En la constelación de respuestas teológicas posibles, se argumenta tanto desde el temor a que se caiga en un sincretismo, como hasta la apreciación de la pluralidad y diversidad religiosa como una oportunidad de profundizar y enriquecer la propia fe cristiana. En este segundo sentido, el pluralismo provocaría y crearía las condiciones idóneas para explorar más plena y dialógicamente la realidad de otras tradiciones religiosas y afirmar nuestra propia identidad como cristianos en un mundo religiosamente plural.

La propia identidad de la tradición cristiana se ha forjado a lo largo de los siglos a partir de contextos, encuentros-desencuentros y caminos diversos, que tampoco fueron unívocos, lineales ni homogéneos. Él se origina en un ambiente 
socio-cultural fundamentalmente judeo-helenista, en un contexto y experiencia de un cristianismo minoritario, extranjero y perseguido en su lucha por definirse a sí mismo, diversificado, impactado y transformado por las tradiciones religiosas, filosóficas y culturales con las que entra en contacto. Esta realidad heterogénea configurante no se reduce a sus orígenes del judeocristianismo, sino que encuentra eco en las experiencias socio-históricas y culturales de las diversas confesiones cristianas, como son, la integración de aspectos culturales en el cristianismo ortodoxo oriental; la conversión de la tradición cristiana en la religión del imperio romano y la configuración de toda una civilización occidental por parte del cristianismo católico romano; la proliferación de confesiones y denominaciones en un marco de afirmación del protestantismo; la inculturación del evangelio en las experiencias de expansión misionera en Asia, África y América Latina; la pluralización de las lecturas teológicas cristianas en los diversos contextos; el auge de las nuevas experiencias de fe de las iglesias carismáticas y pentecostales, entre otras. En todas estas manifestaciones el cristianismo ha evidenciado su capacidad de mostrar nuevos rostros, nuevas aristas que enriquecen y constituyen finalmente aquello que denominamos la tradición cristiana.

El "camino espiritual" del cristianismo ha hecho de éste una tradición religiosa mundial compleja. A medida que el cristianismo trata de vivir entre diferentes culturas, religiones y tradiciones filosóficas e intenta responder a los desafíos actuales y futuros, seguirá transformándose. Es éste el contexto, de un cristianismo que ha estado y está cambiando, donde necesitamos una respuesta teológica a la pluralidad. (Consejo Mundial de Iglesias, 2002: p. 5)

En síntesis, la nueva presencia múltiple, compleja, móvil, permeable, dúctil, no teocrática, de la religión en las sociedades plurirreligiosas contemporáneas, posibilita que se experimenten cambios importantes al interior de la propia religión cristiana. La interacción permanente y estrecha del cristianismo con otras confesiones y religiones, permite que el tema de la pluralidad religiosa deje de ser un problema conceptual o teórico, de interés solo para las academias y facultades de teología por su impacto al interior del discurso teológico, para convertirse en una realidad que impacta la propia creencia y sus fundamentos, la experiencia y vivencia práctica de la fe.

La religión se convierte en un catalizador de la experiencia social concreta que influye en el tejido mismo de la vida en sociedad y crea nuevos paradigmas, nuevas formas de vida, y un nuevo entendimiento de 
sí. También da forma a múltiples relaciones y múltiples pertenencias en nuestras instituciones, nuestras familias e incluso en nosotros mismos. (Aram, 2003: p. 2)

\subsection{El Protestantismo histórico en la configuración de la identidad interreligiosa: la búsqueda de valores comunes.}

El diálogo con otras religiones, en este marco de comprensión de una plurirreligiosidad dialógica antes descrita, ha sido una preocupación central, prioritaria e imperativa del protestantismo histórico desde los orígenes mismos del movimiento ecuménico de raíz protestante. No sería aventurado decir, que su propia autocomprensión como confesión "minoritaria" respecto de las tradiciones católico-romana y ortodoxa, y por tanto, como movimiento de base social limitada, le ha facilitado este abrirse a considerar la otredad religiosa con mayor amplitud. Desde las primeras reuniones del naciente movimiento ecuménico se ha insistido en el carácter testimonial del protestantismo en la sociedad, lo que involucraba su apertura a otras ideas religiosas:

Dar testimonio de Cristo es al mismo tiempo evangelizar y adoptar una actitud profética en la perspectiva del cumplimiento del designio de Cristo de justicia, paz y cuidado de la creación. [...] No se necesitan movimientos e iglesias triunfalistas. Lo que se necesita son discípulos de Cristo fieles, siempre dispuestos a cargar la cruz en amor y solidaridad para con el mundo por el que Cristo murió. (Consejo Mundial de Iglesias, s. f. $)^{15}$

Esta intencionalidad de apertura en lo social no significa, empero, que el protestantismo histórico no sea consciente de las dificultades que han acarreado temas doctrinales controvertidos, posturas fundamentalistas y sectaristas, la intolerancia y no inclusión, los odios y enemistades heredados de las divisiones y cismas, etc., en las rupturas y relaciones tensas tanto con los cristianos de otras denominaciones y confesiones, como con los creyentes de otras religiones.

15 Consejo Mundial de Iglesias, "Conferencia Mundial sobre Misión", http://www. oikoumene.org/es/novedades/news-management/eng/a/article/1634/comienza-en-edimburgola.html (consultada en octubre 22 de 2011). 
El diálogo ecuménico con el evangelismo no histórico se dificulta por algunos aspectos negativos: sectarismo de algunos grupos, su intenso proselitismo, actitud agresiva con la Iglesia Católica, muchas veces definitoria de la identidad propia. También es un obstáculo el hecho de que, por parte de los católicos, se dé con frecuencia un débil sentido de identidad, falta de formación ecuménica, desconocimiento mutuo y el hacer énfasis en los puntos que nos separan, más que en aquellos que nos unen. (Concilio Plenario de Venezuela, s. f.) ${ }^{16}$

Más allá de la vigencia de un análisis y abordaje serio en misionología y soteriología cristiana y de la necesidad de asumir crítica y reflexivamente los temas de conversión, proselitismo, diálogo y encuentro, ecumenismo, tolerancia religiosa, fundamentalismo, entre otros, siguen pesando en el imaginario protestante aquellas posturas dialógicas y de mediación en la consecución de aquello que se resume como "la búsqueda lo que nos une y no de lo que nos separa".

La manera como se visualiza esta búsqueda de elementos comunes en el testimonio de fe protestante, puede ilustrarse a partir de la autocomprensión del protestantismo en dos expresiones concretas, (1) la laxitud teológica de muchas de las iglesias protestantes, a saber, la asunción de la mayoría de dogmas cristianos propios de la iglesia universal - el bautismo, la profesión de fe del Credo Niceno-Constantinopolitano, el dogma trinitario, entre otros - y la aplicación de una criteriología o axiología del dogma que postula ser cuidadosos en aquellas cuestiones centrales, más abiertos y tolerantes en las secundarias ${ }^{17}$; (2) la dinámica de apertura litúrgico-cultual de la tradición protestante histórica, manifiesta en las celebraciones litúrgicamente poco rigoristas y en la celebración del rito eucarístico abierto, por solo citar dos ejemplos.

Quizás la más profunda comprensión de la búsqueda de los elementos comunes por parte del protestantismo histórico ad extra el cristianismo se encuentre en su consideración de los valores religiosos y doctrinales compartidos con las diferentes religiones. Así por ejemplo, con el Judaísmo, las iglesias protestantes

16 Concilio Plenario de Venezuela, “Documento Conciliar No. 15 sobre Ecumenismo y Diálogo Interreligioso", http://www.ocd.com.ve/site/cpv/ecumenismo\%20y\%20dialogo\%20, (consultado en noviembre 1 de 2011).

17 El clérigo anglicano fundador del metodismo John Wesley ilustra lo anterior cuando afirma que se debe sostener en las cosas principales, corrección; en lo secundario, tolerancia; y en todo, caridad. Una de sus frases célebres constituye, "el metodismo no consiste en tener una $\mathrm{u}$ otra determinada doctrina, sino en que pensamos y dejamos pensar". 
comparten su fe y fidelidad al único Dios, el amor a las Sagradas Escrituras y los valores de justicia y paz; con el Islam, también la fe en el único Dios y la sumisión a su voluntad, la relevancia otorgada a la oración, al ayuno y al compartir con los más desfavorecidos; con el Budismo se comparte la búsqueda de lo espiritual y el dominio de los vicios para alcanzar la perfección (santidad y perfección cristiana en el protestantismo), por solo citar algunos ejemplos.

\subsection{La experiencia interreligiosa del protestantismo histórico}

Conviene discernir aquello que ha sido entendido aquí como postura de acercamiento y búsqueda de diálogo interreligioso por parte del protestantismo histórico, en la experiencia concreta del caminar macroecuménico. (Aram, 2003: p. 3)

El primer acontecimiento importante del movimiento ecuménico de origen protestante que tuvo lugar en la modernidad fue la Conferencia Misionera Mundial de Edimburgo en el 1910. Ya la siguiente conferencia, celebrada en Jerusalén en 1928, tuvo entre sus temas cómo comprender y establecer una relación de las otras religiones. En el encuentro en Jerusalén se hizo un llamado a todas las religiones para hacer frente a las consecuencias de la secularización y se produce un debate interesante en torno a la interreligiosidad. Los teólogos asiáticos se mostraron abiertos al análisis de la imbricada relación existente entre la práctica testimonial de la fe en Asia y el transversal componente religioso de toda la cultura asiática. Ante esta postura, considerada en su momento como "pensamiento sincretista", los teólogos occidentales insistieron en la "singularidad de la fe bíblica basada en la revelación divina por medio de Jesucristo" (Aram, 2003: p. 3), es decir, en la unicidad y universalidad de Jesucristo como acontecimiento al interior de la historia de la salvación. Lo interesante de esta confrontación es que desde entonces los teólogos en conjunto reconocieron la existencia de signos y manifestaciones de Dios en las otras tradiciones religiosas.

Las asambleas subsiguientes del Consejo Mundial de Iglesias en Amsterdam (1948) y Evanston (1954) continúan e intensifican el debate, hasta la asamblea de Upsala en 1968 donde se ve la necesidad de asumir el tema del diálogo interreligioso e intercultural como un programa independiente en el Consejo Mundial de Iglesias. Allí se recomendó realizar una consulta específica en el Líbano en 1970, a partir de la cual el Comité Central del Consejo Mundial de Iglesias crea un año después una sección de Diálogo con las Religiones e Ideologías de nuestro Tiempo, que actualmente constituye el Programa de Diálogo y Cooperación Interreligiosos del Consejo Mundial de Iglesias. 
La asamblea de Nairobi de 1975 insiste en la necesidad de discutir y discernir la naturaleza, el objetivo y los límites del diálogo con otras religiones, mientras que en la asamblea de Vancouver de 1983 se produce un debate en torno a la teología de las religiones y se elabora y pone en circulación el documento "La fe de mi prójimo y la mía: descubrimientos teológicos mediante el diálogo interreligioso". Las asambleas subsiguientes (Camberra en 1991, Harare en 1998 y Porto Alegre 2006) continuaron la discusión y la apertura de nuevas cuestiones en el debate sobre el diálogo entre el cristianismo y las otras religiones mundiales. Entre los temas discutidos por el Programa de Diálogo y Cooperación Interreligiosos del Consejo Mundial de Iglesias se encuentran: a) Directrices para el Diálogo con otras religiones (1979); b) casamientos interreligiosos (1994-1997); c) Oración interreligiosa (1997-1998); d) Religiosidades africanas (2000-2004); e) Evaluación de la realidad religiosa (2005-2006, Consulta en Lariano, Italia); f) Familia y comunidad. Economía, mercado y competencia (2006-2007, Consulta en Toulouse, Francia); g) Violencia y política (2008).

Igualmente en los encuentros globales de la Alianza Evangélica Mundial se ha producido un giro copernicano en su concepción del diálogo: al cumplirse los cien años de la primera conferencia de Edimburgo (1910) se hablaba de cambiar del paradigma del ecumenismo intrarreligioso al paradigma del diálogo macroecuménico interreligioso. La Conferencia conmemorativa celebrada en Edimburgo en el 2010 afirmó y reclamó el derecho a la libertad religiosa, siendo que sus asistentes manifestaron en plenaria "una voluntad decidida, firme y clara de diálogo, desde la convicción de que la libertad religiosa y de culto debe ir acompañada de un compromiso responsable y respetuoso de las otras religiones o creencias". (Lupa Protestanto, 2011) ${ }^{18}$

\subsection{Avances protestantes contemporáneos en el diálogo interreligioso}

A nivel de las propuestas conceptuales sobre el diálogo por parte del protestantismo histórico, conviene reseñar uno de los documentos ecuménicos mencionados, producidos por el Programa de Diálogo y Cooperación Interreligiosos del Consejo Mundial de Iglesias que se denomina “Directrices para el diálogo con

18 Lupa Protestante, "Edimburgo 2010", http://www.lupaprotestante.com/redsocial/ index.php/home/columnistas/manuel-lopez/2001-madrid-1870--edimburgo-1910--alicante-2010 (consultada en noviembre 2 de 2011). 
creyentes de otras religiones", elaborado en 1979 y revisado y actualizado en 2002. El documento parte por asumir que objetivamente para muchos creyentes de iglesias protestantes resulta difícil entrar en interrelación con otras tradiciones religiosas. Sin embargo, se afirma que la acción del Espíritu de Dios se encuentra y actúa más allá de las definiciones y preconcepciones limitadas de nuestro entendimiento (Jn 3, 8) y de lo que se trata es de discernir la manifestación de la presencia de Dios allí donde hay amor, gozo, paz, fe, mansedumbre y templanza (Gal 5, 22-23). (Consejo Mundial de Iglesias, s. f. $)^{19}$ En este sentido, continúa con la exposisión el documento en su numeral 17:

En el diálogo y las relaciones con personas de otras religiones, hemos podido comprender que nuestras afirmaciones teológicas no agotan el misterio de la salvación de Dios. La salvación pertenece a Dios. De ahí que no podamos tener la temeridad de erigirnos en jueces de otros. Mientras damos testimonio de nuestra fe, tratamos de entender los caminos por los que Dios se propone dar cumplimiento a sus designios. [...] De ahí que podamos asegurar a nuestros interlocutores en el diálogo que somos sinceros y francos en nuestro deseo de caminar juntos hacia la plenitud de la verdad. [...] De ahí que proclamemos con confianza esa esperanza, preparados para dar razón de ella mientras luchamos y obramos junto con otros en un mundo desgarrado por rivalidades y guerras, desigualdades sociales e injusticias económicas. (Consejo Mundial de Iglesias, s. f.)

Finalmente, se aportan en el documento una serie de principios y consideraciones prácticas a la hora de asumir el diálogo y las relaciones interreligiosas, y se describe cuáles serían aquellos principios rectores de un diálogo tal, que valen la pena reseñar:

1. El diálogo debe ser un proceso de enriquecimiento mutuo, no afirmado con base en relaciones de poder, sino en la acción constructiva en bien de todos los seres humanos.

19 Cf. Consejo Mundial de Iglesias, "Consideraciones ecuménicas sobre el diálogo y las relaciones con creyentes de otras religiones", Numeral 14, http://www.oikoumene.org/ es/documentacion/documents/programas-del-cmi/interreligious-dialogue-and-cooperation/ interreligious-trust-and-respect/04-consideraciones-ecumenicas-sobre-el-dialogo-y-lasrelaciones-con-creyentes-de-otras-religiones.html, (consultada en octubre 28 de 2011). 
2. En el diálogo se crece y profundiza en la fe, en la reconsideración constante de la comprensión e interpretación de la tradición bíblica y teológica.

3. En el diálogo se afirma la esperanza de que en medio de las muchas divisiones, conflictos y violencia, es posible formar una comunidad humana que viva en justicia y paz.

4. El diálogo no es un fin en sí mismo, sino un medio para construir puentes de respeto y comprensión; una gozosa afirmación de vida para todos.

5. En el diálogo se cultivan las relaciones y lazos con los que consideramos como "los otros".

6. En el diálogo resulta esencial ser conscientes de los datos de la realidad y el contexto (experiencia histórica, coyuntura económica e ideológica, las diferencias de cultura, sexo, edad, raza e identidad étnica). La finalidad del diálogo no es eliminar las diferencias, sino establecer relaciones de confianza en el respeto de esas diferencias.

7. En el diálogo, avanzamos hacia el respeto mutuo en la escucha de la comprensión de la fe de la otra parte. La confianza se construye en la libre expresión de los interlocutores, dando oportunidades para cuestionarse mutuamente, sin dejar de lado, si procede, las críticas justificadas.

8. En el diálogo, es importante respetar la integridad de las tradiciones religiosas en la diversidad de sus estructuras y organizaciones

9. La cooperación y la colaboración están en el centro del diálogo de manera que todos los participantes tienen que ser incluidos en el proceso de planificación desde el principio.

En el diálogo se procura ser incluyentes de los diferentes niveles, sectores, y grupos, ya que el diálogo puede derivar fácilmente hacia una actividad elitista y quedar limitado a ciertos sectores de la sociedad. (Consejo Mundial de Iglesias, s. f.)

Lo que muestra esta aproximación, que no es más que un análisis y balance de los treinta años de diálogo interreligioso por parte del movimiento ecuménico de fuerte matiz protestante, es que se ha producido un cambio de enfoque importante en la perspectiva sobre el diálogo interreligioso. Los temas puramente doctrinales y/o académicos de las asambleas primeras del Consejo Mundial de Iglesias han sido desplazados y han cedido lugar a la aquellos problemas de la vida social, la cotidianidad, las relaciones económicas y políticas, entre otras. Se trata aquí de un diálogo "para la vida", donde se involucra en el diálogo mismo 
las relaciones de vida, la posibilidad de producción y reproducción de la vida social de la humanidad entera. De alguna manera, en la posibilidad del diálogo del protestantismo con la religión "otra" se juega su propia sobrevivencia. Por otro lado, la preocupación por el diálogo se ha hecho prioritaria y ya no se circunscribe a un único programa del Consejo Mundial de Iglesias:

De una u otra forma, casi todos los programas del Consejo se ocupan de cuestiones o problemas que atañen al diálogo, las relaciones y la colaboración con otras religiones. Muchos consejos de iglesias regionales o nacionales y estructuras ecuménicas, han dado al diálogo un lugar importante en sus reflexiones como forma de responder a la realidad mundial en constante evolución y a la situación religiosa en la que viven, e incluso lo han incluido en su marco programático. (Aram, 2003: p. 3)

No obstante la evidente evolución del diálogo interreligioso en un sentido positivo, éste sigue siendo una de las causas de controversias y desencuentros entre las iglesias protestantes históricas. El recelo en relación a los objetivos mismos del diálogo y el cuestionamiento sobre la validez y legitimidad de otras religiones continúan siendo uno de los obstáculos para el logro de mayores avances en la materia. De manera que el diálogo interreligioso a la fecha permanece como aquella dimensión más compleja y controvertida del movimiento ecuménico de trasfondo protestante.

\subsection{Perspectiva teológica protestante: hacia una teología de las religiones}

Algunos teólogos protestantes hablan de una necesaria "teología de las religiones" y aún más, de una "teología holística incluyente". Frente a estas propuestas la pregunta sería por los límites de un "hablar de Dios desde las circunstancias actuales" (W. Kasper), los límites de un hablar teológico encarnado en las circunstancias plurirreligiosas actuales. En cualquier caso, la plurirreligiosidad social resulta el contexto ineludible, y por tanto, el locus teológico desde el cual asumir el discurso teológico cristiano: un contexto que insta a la búsqueda de nuevas formas de hacer teología. En este sentido, la teología protestante ha planteado algunos temas y dimensiones teológicas que serían necesarias profundizar, reactualizar y releer conforme a los signos de los tiempos plurirreligiosos presentes. Una de ellas, que se desea resaltar aquí es la cuestión cristológica y soteriológica. 
A nivel de la Cristología conviene tomar en cuenta fundamentalmente la dimensión soteriológica, a partir de aquellos dogmas cristológicos elaborados por la iglesia cristiana referidos a la acción redentora y salvadora de Jesucristo al interior de la economía de la salvación. La pregunta teológica controversial a dirimir tiene que ver con el lugar que ocupan los creyentes de otras religiones dentro del plan y acción salvífica de Dios en la historia de la salvación, toda vez que se afirma el carácter único y universal de la salvación mediada por Jesucristo. A este respecto ha primado una respuesta tradicionalmente categórica que sostiene que toda religión o persona religiosa que no acepte a Jesucristo como su salvador está desprovista de verdad.

La producción teológica del movimiento ecuménico de los últimos años ha ampliado su concepción cristológica al menos en dos sentidos: (1) afirmando el criterio de "inclusión" presente en todo el mensaje, ministerio público y pretensión de Jesús de Nazaret, el cual se reproducen en el kerigma evangélico de las primeras comunidades cristianas de que "en Cristo todos serán vivificados" (1 Co 15, 22); y (2) reinterpretando la transformación dentro de la historia del cristianismo de un contenido "teocéntrico" presente en la predicación de Jesús, hacia una contenido "cristocéntrico" en la predicación postpascual. Tomando en cuenta estos dos aspectos resulta posible para la teología protestante ecuménica considerar a las otras religiones y creencias como parte del plan o designio salvífico de Dios, en tanto estas no contradigan fundamentalmente la revelación de Dios en Jesucristo. ${ }^{20}$

El Movimiento Ecuménico ha ampliado el alcance de nuestro pensamiento cristológico. El centro de la economía de salvación de Dios es el acontecimiento de Cristo, pero no puede limitarse a su revelación en la historia; abarca a toda la humanidad y toda la creación y se expresa de diferentes formas. (Consejo Mundial de Iglesias, 1997, 418)

En este sentido la acción salvadora de Dios trascendería los límites y márgenes de la iglesia, aun cuando ella siga siendo sacramento y presencia mistérica de Dios mismo en medio de la humanidad. De lo que se trata aquí, según la teología interreligiosa propuesta por el movimiento ecuménico protestante es volver

20 Varias producciones cristológicas se dirigen en esta línea como las elaboradas por el teólogo católico español Raimon Panikkar y el teólogo indú Mammen Thomas al hablar del "Cristo oculto o desconocido". Igualmente el teólogo protestante indú Stanley Samartha ha propuesto un "sincretismo cristocéntrico" y el teólogo católico belga Jacques Dupuis se refiere a una complementariedad y convergencia entre el cristianismo y otras religiones. 
al sentido primigenio del cristianismo, que antes que dogma cristocéntrico, fue euangelion, "buena noticia" de inclusión, amor, compasión y acogida del otro/a diferente, distinto, también desde el punto de vista religioso (cf. Gal 5, 22). La exclusión, el rechazo, la arrogancia, la condescendencia y la actitud de menosprecio no serán evangelio de salvación y salud para la humanidad, sino una "mala noticia". Desde el punto de vista cristológico se trata igualmente de discernir aquellos "valores crísticos" de la predicación de Jesús sobre el Reino de Dios (justicia, solidaridad, amor, reciprocidad, inclusión) presentes también en otras religiones, de manera que se logre "despertar" al Cristo implícito en la teología de otras religiones.

Tal como lo reseña el Moderador del Consejo Mundial de Iglesias para el Diálogo Interreligioso, el Patriarca de la Iglesia Apostólica de Armenia (Sede de Cilicia), S.S. Aram I, la Conferencia del Consejo Mundial de Iglesias de San Antonio aportó en este sentido: “No podemos indicar ningún otro camino de salvación que Jesucristo, y, al mismo tiempo, no podemos poner límites al poder de salvación de Dios (...). Apreciamos esa tensión y no tratamos de resolverla" (Consejo Mundial de Iglesias, 1990: p. 7). En cualquier caso, no se trata necesariamente de cambiar nuestras hermenéuticas teológicas actuales, más sí de que la teología protestante se deje impactar e interpelar por la plurirreligiosidad, más preparada para un diálogo profundo y realmente significativo con las otras religiones.

\section{Conclusiones}

Finalmente, se tendría que afirmar que la tradición de cristianismo protestante, deudor de una larga tradición de fe crítica, ilustrada y humanizadora, y cuya expresión dialógica interreligiosa a nivel mundial la constituye el movimiento ecuménico de iglesias protestantes históricas, se encuentra desde hace un siglo, como ha sido visto, abierto al encuentro y al diálogo entre las religiones y enfrascado en la búsqueda de unos elementos comunes para validar y hacer factible éste. Esa fe protestante parte del compartir unos signos de humanidad común con el resto de los creyentes de otras religiones, y por lo mismo, de verse enfrentado a idénticos límites que imponen los problemas y conflictos de esa misma humanidad. Su "común" ser y existencia en el mundo ha resultado señal inequívoca de la necesaria aproximación a la solución común de conflictos y a la búsqueda de la paz en la medida en que como ha afirmado el teólogo católico alemán Hans Küng, "no habrá paz en el mundo sin paz religiosa; y no habrá paz religiosa sin diálogo entre las religiones" (Küng, 1991). 
Desde el protestantismo histórico de trata de una apuesta por un diálogo de vida, por un diálogo para la vida que debe abarcar todos los aspectos de la existencia humana, desde las cuestiones sociales, económicas, políticas, culturales, hasta los aspectos teológicos doctrinales más espinosos. En este sentido, "el diálogo no es un mero intercambio de opiniones; es la experiencia de vivir juntos, de reflexionar juntos y de trabajar juntos" (Aram, 2003: p. 12) aquello que lo constituye. La teología protestante y las iglesias protestantes históricas tendrán que seguir asumiendo el desafío de, no solo orar junto a los hermanos de otras confesiones y religiones, sino también pensar juntos y afirmar su propia identidad cristiana protestante, en la medida en que continúe asumiendo ante los creyentes de todas las religiones que,

La pluralidad de las tradiciones religiosas es el resultado de las múltiples maneras en que Dios se ha relacionado con los pueblos y las naciones, pero también la manifestación de la riqueza y diversidad de la respuesta humana a los dones de gracia de Dios. [...] Es nuestra fe en el Dios trinitario, el Dios que es diversidad en la unidad, el Dios creador, da plenitud, alimenta y sostiene, la que nos ayuda en nuestra hospitalidad de apertura a todos. Hemos recibido la generosa hospitalidad de amor de Dios. No podemos hacer de otro modo. (Consejo Mundial de Iglesias, 1990: p. 9)

\section{Referencias}

Amestoy, N. (2007). Ascética protestante y modernidad en el Río de la Plata (18751900). En: Teología y cultura, Año 4, Vol. 8.

Aram I, (2003). Informe del Moderador de Dialogo Interreligioso ante el Comité Central del Consejo Mundial de Iglesias. Ginebra: WCC Publications.

Cervantes, L. (2002). Protestantismo, protestantismos e identidad en América Latina y México, [Ponencia XVI Congreso Nacional Estado, Iglesias y Grupos laicos]. Puebla: Universidad Autónoma de Puebla.

Bastian, J. P. (Coord.) (2004). La modernidad religiosa: Europa latina y América Latina en perspectiva comparada. México: FCE,.

. (1990). Historia del protestantismo en América Latina (México: CUPSA, 1990).

. (1983). Protestantismo y sociedad en México. México: CUPSA.

Berg, M. y Pretiz, P. (1994). Mensajeros de esperanza: los evangélicos. Miami: UNILIT. 
Consejo Mundial de Iglesias (WCC), (s. f.). Consideraciones ecuménicas sobre el diálogo y las relaciones con creyentes de otras religiones. En: http:// www.oikoumene.org/es/documentacion/documents/programas-del-cmi/ interreligious-dialogue-and-cooperation/interreligious-trust-and-respect/04consideraciones-ecumenicas-sobre-el-dialogo-y-las-relaciones-con-creyentesde-otras-religiones.html, [consultado: en octubre 28, 2011].

Consejo Mundial de Iglesias (WCC), (1990). The San Antonio Report. Ginebra: WCC Publications.

Consejo Mundial de Iglesias (WCC), (2005). Pluralidad religiosa y autocomprensión cristiana. Ginebra: WCC Publications.

Hinkelammert, F. (1995). Cultura de la esperanza y sociedad sin exclusión. San José: DEI.

Küng, H. (1991). Proyecto de una ética mundial. Madrid: Trota.

Lupa Protestante (s. f.) "Edimburgo 2010". En: http://www.lupaprotestante.com/ redsocial/index.php/home/columnistas/manuel-lopez/2001-madrid-1870-edimburgo-1910--alicante-2010. [consultado: noviembre 2 de 2011].

Míguez, J. (1995). Rostros del protestantismo latinoamericano. Buenos Aires: Nueva Creación.

. (1985). Historia y misión. En: Richard, P. (Ed.), Raíces de la teología latinoamericana. San José: DEI.

Míguez, J. y Álvarez, C. (1983). Protestantismo y liberalismo en América Latina. San José: DEI-SEBILA.

Moreno, P. (Dir.), (2009). La acción social de las iglesias evangélicas en Colombia. Bogotá: CEDECOL.

Orellana, L. (2006). El fuego y la nieve. Historia del movimiento pentecostal en Chile: 19091932. Santiago: CEEP.

Saranyana, J. I. (Dir.), (2002). Teología en América Latina, Vol. III “El siglo de las teologías latinoamericanas. Madrid: Iberoamericana.

Schäfer, H. (1992). Protestantismo y crisis social en América Central. San José, DEI.

Tamayo, J. J. (2004). Fundamentalismo y diálogo entre religiones. Madrid, Trotta. 